\title{
SYSTEMATIC REVIEW: EFEKTIVITAS Ideonella sakaiensis DAN Chlamydomonas reinhardtii SEBAGAI AGEN BIODEGRADASI PLASTIK BERBAHAN DASAR PET
}

\author{
Fadhlan Musdary ${ }^{1 *}$, Lisa Amalia1, Reza Maulana Ahmad Lubis ${ }^{1}$, Widia Ningsih ${ }^{1}$ \\ ${ }^{1}$ Universitas Negeri Medan \\ *fadhlanmusdary1234@gmail.com
}

\begin{abstract}
ABSTRAK
Bakteri Ideonella sakaiensis dan microalga Chlamydomonas reinhardtii dapat mendegradasi plastik PET (Poly-ethylene terephthalate) dengan mensintesiskan enzim PETase. Tujuan penelitian ini adalah untuk mengetahui efektivitas dari bakteri Ideonella sakaiensis dan Chlamydomonas reinhardtii sebagai agen biodegradasi plastik berbahan dasar PET. Penelitian ini merupakan Systematic Review, yang dilakukan dengan membandingkan dan menganalisis artikel-artikel yang diambil dari database digital seperti Springer Link dan Semanthic Schoolar. Artikel-artikel yang telah dicari dengan keyword yang telah ditentukan, kemudian dieksklusi sesuai dengan parameter yang ditetapkan, sehingga didapat 2 artikel rujukan. Hasil review menunjukkan bakteri I. sakaiensis mampu mendegradasi PET menjadi MHET (Monoterephtalic Hydroxyethyl Terephtalate) yang lebih dominan dibanding BHET (Bishydroxyethyl Terephtalate) \& TPA (Terephthalate Acid), sedangkan C. reinhardtii mendegradasikan PET menjadi TPA. Bakteri I. sakaiensis memerlukan waktu 18 jam untuk dapat mendegradasi $30 \%$ dari PET film sedangkan C.reinhardtii memerlukan waktu 4 minggu untuk dapat mendegradasi 35,17\% dari PET powder. Kedua mikroorganisme tersebut memiliki keefektifan yang berbeda dalam setiap parameter, yaitu hasil degradasi dan lama waktu pendegradasian.
\end{abstract}

Kata Kunci: Biodegradasi, Chlamydomonas reinhardtii, Ideonella sakaiensis, PET, Systematic Review

\begin{abstract}
Ideonella sakaiensis and Chlamydomonas reinhardtii can degrade PET (Poly-ethylene terephthalate) plastic by synthesizing the PETase enzyme. The purpose of this study was to determine the effectiveness of the bacteria Ideonella sakaiensis and Chlamydomonas reinhardtii as PET-based plastic biodegradation agents. This research is a Systematic Review, which is conducted by comparing and analyzing articles taken from digital databases such as Springer Link and Semanthic Schoolar. Articles that have been searched with predetermined keywords are then excluded according to the specified parameters, so that 2 reference articles are obtained. The results of the review showed that I. sakaiensis was able to degrade PET to MHET (Monoterephtalic Hydroxyethyl Terephtalate) which was more dominant than BHET (Bis-hydroxyethyl Terephtalate) \& TPA (Terephthalate Acid), while C. reinhardtii degraded PET to TPA. It took I. sakaiensis 18 hours to degrade 30\% of PET film while C. reinhardtii took 4 weeks to degrade $35.17 \%$ of PET powder. The two microorganisms have different effectiveness in each parameter, namely the results of degradation and the length of time for degradation.
\end{abstract}

Keywords: Biodegradation, Ideonella sakaiensis, Chlamydomonas reinhardtii, PET, Systematic Review

\section{PENDAHULUAN}

Mayoritas plastik di dunia berbahan dasar PET. Botol yang berbahan dasar plastik PET dirokemendasikan hanya sekali pakai, karena apabila sering digunakan ikatan polimer PET pada plastik akan terlepas dan mengeluarkan zat yang bersifat karsinogenik (penyebab kanker). Selain itu plastik dapat mencemari lingkungan, ikatan polimer plastik sangat kuat sehingga sulit terurai di dalam tanah (Karuniastuti, 2013). 


\section{Jurnal Biolokus: Jurnal Penelitian Pendidikan Biologi dan Biologi Vol.4(1)}

Sejak tahun 1940-an PET dianggap sebagai salah satu Polimer sintetik yang paling banyak digunakan, dengan penggunaan mendekati 50 miliar ton (McIntyre, 2004). Berdasarkan data Kementerian Lingkungan Hidup dan Kehutanan (KLHK) serta Kementrian Perindustrian Indonesia Tahun 2016, jumlah timbunan sampah di Indonesia sudah mencapai 65,2 juta ton per-tahun. Lebih lanjut, data KLHK menyebutkan total jumlah sampah Indonesia di 2019 mencapai 68 juta ton, dan sampah plastik diperkirakan mencapai 9,52 juta ton atau 14 persen dari total sampah yang ada (Karuniastuti, 2013). Selain itu, pandemi COVID-19 juga telah menyebabkan peningkatan produksi sampah plastik di Indonesia. Survey Lembaga Ilmu Pengetahuan Indonesia (LIPI) menunjukkan bahwa terjadi peningkatan kegiatan belanja online 2 kali lipat dari biasanya, yang mana $96 \%$ dari pembungkusnya merupakan material berbahan plastik (Nurhati, 2020). Untuk itu, akan sangat menguntungkan apabila memanfaatkan agen mikrobiologi yang mampu mendegradasi PET tersebut.

Bakteri yang pertama kali ditemukan mampu mendegradasi PET adalah Ideonella sakaiensis. Bakteri ini dapat mensekresikan PETase, yaitu sebuah enzim yang mampu mendegradasi PET menjadi bentuk yang sederhana (Fitriyano, 2019). Penelitian lainnya juga melaporkan bahwa microalga perairan seperti Phaeodactylum tricornutum dapat membantu proses degradasi sampah plastik yang mencemari air laut (Moog et al., 2019).

Penelitian ini bertujuan mengetahui efektivitas bakteri Ideonella sakaiensis dan microalga Chlamydomonas reinhardtii sebagai agen biodegradasi plastik berbahan dasar PET. Karena penelitian mengenai agen biodegradasi PET di Indonesia saat ini masih sedikit, maka dirasa penting untuk dilakukan penelitian berbasis systematic review ini.

\section{Poly-ethylene Terephthalate}

PET merupakan bahan yang bersifat karsinogenik, suhu yang tinggi dapat meningkatkan terlepasnya zat itu. Akan tetapi, pembakaran sampah plastik bukanlah solusi yang tepat, karena akan menghasilakan zat sisa pembakaran yang dapat membahayakan sistem pernafasan (Warlina, 2019). Suhu optimum dalam pencairan PET adalah $110^{\circ} \mathrm{C}$. Selain itu, PET memiliki sifat permiabilitas yang tinggi (Sulchan \& Nur W, 2007).

Mittal et al. (2010) melakukan penelitian mengenai analisis PET dengan enzim Aminolysis dan Ammonolysis yang merupakan katalis. Hasil yang didapatkan adalah proses degradasi PET jauh lebih cepat dengan adanya katalis, kehadiran katalis akan merusak polimer PET. Setelah 45 hari PET yang diperlakukan dengan katalis, tidak menyisakan sisa sisa flaks lagi pada PET. Proses pirolisis PET juga membutuhkan katalisis untuk mempercepat reaksinya, hal ini dibuktikan dengan penelitian (Damayanti et al., 2015), semakin banyak katalis yang berperan dalam Pirolisis PET, semakin banyak produk PET cair yang dihasilkan.

\section{Enzim PETase}

PETase merupakan enzim yang dapat mengkatalis reaksi dalam penguraian PET. Mekanismenya adalah PETase akan menghidrolisis permukaan serabut (Kawai et al., 2019) (Gambar 1). Hidrolisis enzim PETase dapat meningkat di lingkungan bersuhu tinggi yang akan mengakibatkan putusnya rantairantai polimer (Mueller, 2006).
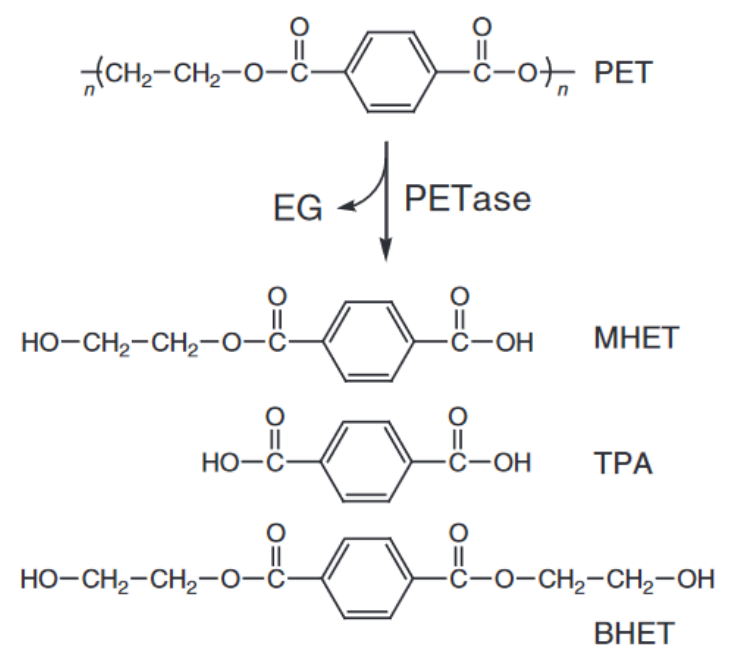

Gambar 1. Reaksi mekanisme PETase dalam hidrolisis serabut PET. (Sumber: Han et al., 2017) 


\section{Jurnal Biolokus: Jurnal Penelitian Pendidikan Biologi dan Biologi Vol.4(1)}

Banyak enzim telah diujicoba untuk menghidrolisis PET, seperti lipase dari Candida antarctica, kutinase dari jamur Aspergillus oryzae, esterase dari Thermobifida haloterans, bahkan protease yang dapat meningkatkan hidrofilisitas polyester. Namun, enzim - enzim tersebut kurang efisien untuk mendegradasi blok PET (Kawai et al., 2019). Enzim PETase dapat mengurai (PET) menjadi MHET (Monoterephtalic Hydroxyethyl Terephtalate) yang merupakan bentuk sederhana dari PET (Seo et al., 2019) (Gambar 2). PETase lebih efektif dan efisien dibanding enzim penghidroloisis PET lainnya, karena PETase dapat menghidrolisis PET dengan difusi enzim yang lebih sedikit (Yoshida et al., 2016).

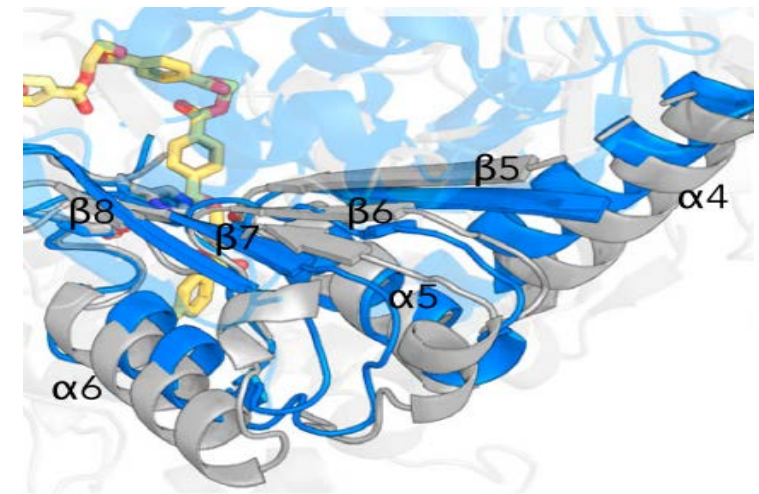

Gambar 2. Struktur 3D Enzim PETase (Biru) \& Enzim MHETase (Abu-Abu).

(Sumber: Knott et al., 2020)

\section{Bakteri Ideonella sakaiensis}

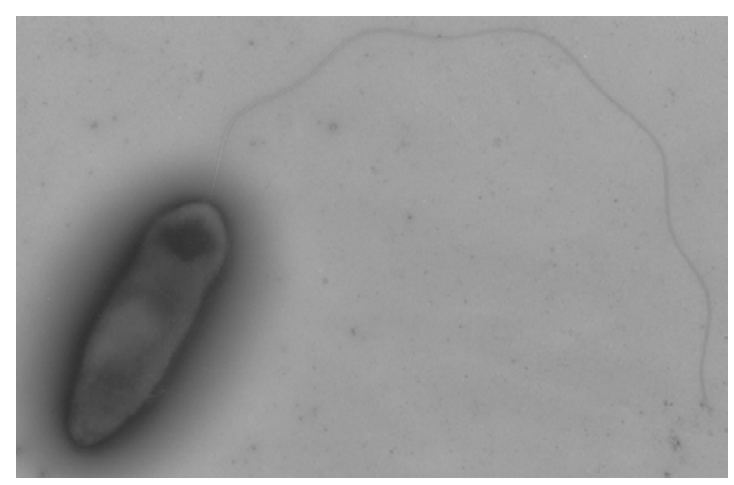

Gambar 3. Morfologi Ideonella sakaiensis.

(Sumber: Tanasupawat et al., 2016)

Bakteri Ideonella sakaiensis (Gambar 3) dengan tipe strain 201 - F6 pertama kali diisolasi oleh (Tanasupawat et al., 2016) di kota Sakai, Jepang. Bakteri I. sakaiensis merupakan bakteri gram negatif, aerobik, berbentuk batang, motil dengan flagella berbentuk polar. Bakteri ini hidup dengan berkoloni, dan berbentuk sirkular.

I. sakaiensis mampu mensekresikan beberapa senyawa organik serta enzim. Senyawa organik yang dihasilkan meliputi Nasetil glukosamin, maltosa, kalium glukonat, asam adipat, asam malat, dan sitrat, sedangkan enzim yang disintesis terdiri dari asam fosfatase, naftolAS-BI-phosphohydrolase. I. sakaiensis juga mensintesis PET hidrolase atau PETase, yaitu enzim yang dapat memecah rantai polimer PET pada rentang suhu optimum $20-400^{\circ} \mathrm{C}$. Bakteri ini mengikat PET dan mensekresikan PETase ke substrat (Yoshida et al., 2016)

\section{Microalga Chlamydomonas reinhardtii}

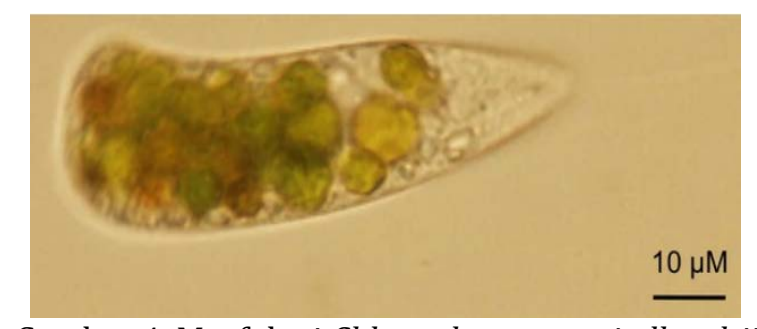

Gambar 4. Morfologi Chlamydomonas reindhardtii (Sumber: Sasso et al., 2018)

Chlamydomonas reinhardtii adalah mikroorganisme uniseluler \& fotoautotrof. Mikroorganisme ini memiliki kelebihan untuk digunakan dalam praktek biodegradasi karena dianggap aman dan bersahabat dengan lingkungan. C. reindhardtii juga dapat mensekresikan enzim PETase (Kim et al., 2020).

\section{METODE}

Penelitian ini merupakan penelitian systematic review. Menurut (Khan et al., 2003) terdapat 5 tahap dalam pelaksanaannya (Gambar 5), yaitu: 1) framing question, penyusunan pertanyaan yang ditujukan untuk menjawab permasalahan dalam penelitian. Pertanyaan ini menjadi dasar berjalannya proses review; 2) identifying relevant work, pencarian artikel yang dilakukan pada 2 database digital yakni Springer Link dan Semanthic Schoolar dengan menggunakan 5 
Fadhlan Musdary et al., Systematic Review: Efektivitas Ideonella sakaiensis dan Chlamydomonas reinhardtii sebagai Agen Biodegradasi Plastik Berbahan Dasar PET

\section{Jurnal Biolokus: Jurnal Penelitian Pendidikan Biologi dan Biologi Vol.4(1)}

keyword yakni PETase, penguraian plastik, $I$. sakaiensis dan C. reinhardtii dalam Bahasa Indonesia maupun Bahasa Inggris. Kriteria inklusi yang ditetapkan ialah artikel ditulis dalam Bahasa Indonesia atau Bahasa Inggris, terbit sejak 2016 dan harus memiliki DOI; 3) assesing the quality of studies, penilaian terhadap artikel-artikel yang diperoleh untuk menguji kelayakannya, artikel yang dianggap tidak layak dengan alasan tertentu akan dieksklusi. 4) summarizing the evidence, analisis sistematis terhadap artikel yang dianggap layak, membandingkannya dan membuat ringkasan analisis tersebut; 5) interpreting the findings, interpretasi terhadap artikel yang telah diinklusi untuk menjawab permasalahan yang telah dirumuskan sebelumnya.

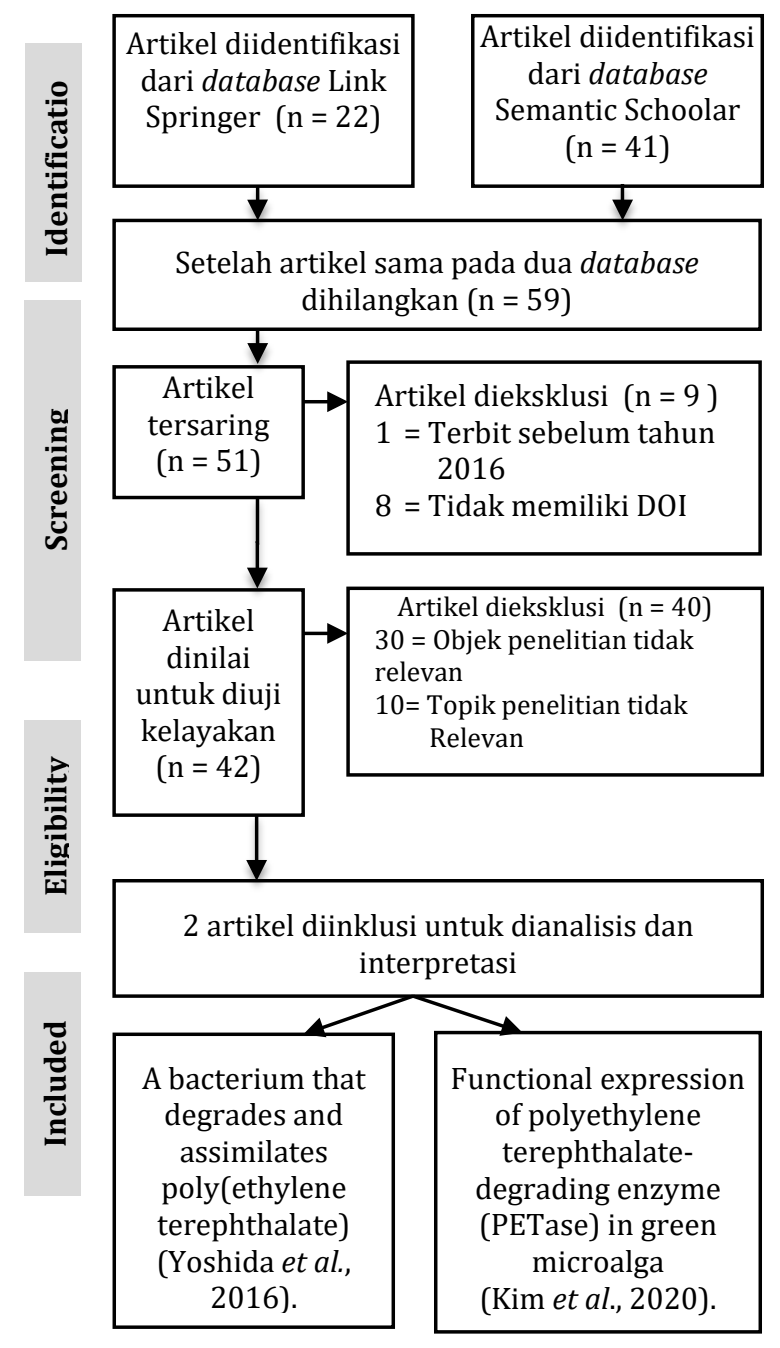

Gambar 5. Diagram alir proses eksklusi dan inklusi artikel dalam tahapan systematic review (n=jumlah artikel).

\section{HASIL DAN PEMBAHASAN}

Review yang dilakukan terhadap dua artikel yang memenuhi kriteria inklusi menunjukkan terdapat perbandingan antara efektivitas dari penggunaan I. Sakaiensis dan $C$. reinhardtii sebagai agen biodegradasi plastik berbahan dasar PET.

Tabel 1. Analisis perbandingan I. sakaiensis dan C. reinhardtii sebagai agen biodegradasi plastik berbahan dasar PET

\begin{tabular}{|c|c|c|}
\hline \multirow[b]{2}{*}{ Parameter } & \multicolumn{2}{|c|}{ Author } \\
\hline & $\begin{array}{c}\text { (Yoshida et } \\
\text { al., 2016) }\end{array}$ & $\begin{array}{l}\text { (Kim et al., } \\
\text { 2020) }\end{array}$ \\
\hline Jenis Organisme & $\begin{array}{l}\text { Ideonella } \\
\text { sakaiensis }\end{array}$ & $\begin{array}{c}\text { Chlamydomonas } \\
\text { reinhardtii }\end{array}$ \\
\hline Enzim pendegradasi & PETase & PETase \\
\hline Jenis Plastik & $\begin{array}{c}\text { PET film } \\
(2 \mathrm{~cm} \mathrm{x} \\
1,5 \mathrm{~cm})\end{array}$ & $\begin{array}{l}\text { PET powder } \\
\quad(30 \mathrm{mg})\end{array}$ \\
\hline Suhu Inkubasi & $30^{\circ} \mathrm{C}$ & $30^{\circ} \mathrm{C}$ \\
\hline $\mathrm{pH}$ Inkubasi & 7.0 & 7.0 \\
\hline $\begin{array}{l}\text { Lama Waktu } \\
\text { Pendegradasian }\end{array}$ & 18 jam & 4 minggu \\
\hline $\begin{array}{l}\text { Komponen yang } \\
\text { terurai }\end{array}$ & $\begin{array}{l}\text { 30\% dari } \\
\text { keseluruhan } \\
\text { PET film }\end{array}$ & $\begin{array}{l}35,17 \% \text { dari } \\
\text { keseluruhan } \\
\text { PET powder }\end{array}$ \\
\hline Hasil Penguraian & $\begin{array}{c}\text { MHET } \\
\text { (dominan), } \\
\text { BHET, TPA }\end{array}$ & TPA \\
\hline
\end{tabular}

Berdasarkan Tabel 1, I. sakaiensis dan C. reinhardtii keduanya memiliki enzim pendegradasi yaitu PETase. Pada Bakteri $I$. sakaiensis jenis plastik yang didegradasikan yaitu PET film $(2 \mathrm{~cm} \times 1,5 \mathrm{~cm})$, sedangkan $C$. reinhardtii jenis plastik yang didegradasi yaitu PET powder (30mg). Suhu inkubasi dan $\mathrm{pH}$ inkubasi dari kedua organisme sama, dengan suhu $30^{\circ} \mathrm{C}$ dan $\mathrm{pH}$ 7.0.

Lama waktu yang dibutuhkan dalam pendegradasi sampah plastik, I. sakaiensis memerlukan waktu 18 jam untuk dapat mendegradasi plastik $30 \%$ dari PET film sedangkan $C$. reinhardtii memerlukan waktu 4 minggu untuk dapat mendegradasi plastik 35,17 \& dari PET powder. Dapat dikatakan bahwa bakteri I. sakaiensis dapat mendegradasikan PET 1,7\% dari bagian PET per jam. Sedangkan $C$. reindhardtii hanya mampu mendegradasikan PET $0.05 \%$ per jam. Menurut (Farzi et al., 2019) bahwa semakin kecil ukuran PET maka semakin cepat pula PET tersebut akan terdegradasi. 
Jurnal Biolokus: Jurnal Penelitian Pendidikan Biologi dan Biologi Vol.4(1)

Seharusnya pendegradasian PET powder lebih cepat dibanding pendegradasian PET Film. Akan tetapi $C$. reindhardtii memakan waktu yang lama dari I. sakaiensis. Oleh karena itu, apabila ditinjau dari segi waktu I. sakaiensis lebih efektif dibanding C. reindahrtii.

Penguraian plastik oleh I. sakaiensis menghasilkan MHET yang lebih dominan dibanding BHET \& TPA, Sedangkan C. reinhardtii menghasilkan TPA. MHET merupakan produk utama yang dihidrolisis oleh PETase beserta produk produk tambahan seperti TPA dan BHET. PETase ini juga yang akan menghidrolisis BHET menjadi MHET (Yang et al., 2016) PETase adalah Enzim yang mengkatalis reaksi PET menjadi MHET dan MHETase adalah enzim yang mengkatalis reaksi MHET menjadi TPA dan EG sebagai produk akhirnya (de Castro et al., 2017).

Sedangkan Terephthalate Acid merupakan bahan baku penyusun Poliester. Namun baru - baru ini TPA sering digunakan sebagai penyusun film PET yang merupakan bahan dasar penyusun botol plastik. Akibat bentuk penggunaannya berskala besar, TPA merupakan polutan bagi lingkungan dan sering mencemari tanah, perairan, bahkan organisme akuatik. TPA bahkan dapat mempengaruhi sistem reproduksi manusia (Thiruvenkatachari et al., 2007). Peneliti lain mengujicobakan mencit yang makanannya telah diinduksi TPA, hasilnya konsentrasi testosterone pada mencit eksperimen lebih sedikit dibanding yang dihasilkan tikus kontrol (Shinshi \& Kogo, 1980). Oleh karena itu, TPA merupakan material yang berbahaya bagi lingkungan.

$$
\text { Hasil biodegredasi microalga }
$$

C.reindhardtii merupakan hasil yang sudah sangat sederhana berupa TPA. Begitu juga dengan agen biodegredasi bakteri I. sakaiensis yang dapat mendegredasi PET menjadi TPA, namun hasil yang paling dominan adalah hasil yang belum sesederhana TPA yaitu MHET. Artinya C. reindhardtii mampu mendegradasikan PET menjadi hasil yang paling sederhana, namun membutuhkan waktu yang lama.
Jika ditinjau dampak lingkungan $I$. sakaiensis dianggap sebagai pencemar, karena memiliki struktur endotoksin dan membutuhkan banyak Karbon untuk pertumbuhannya (Kim et al., 2020). Endotoksin merupakan bagian struktur dari dinding sel bakteri gram negatif yang memproduksi racun (Triyaningsih et al., 2008). Pertumbuhan bakteri I. sakaiensis yang sangat cepat merupakan ancaman lain bagi lingkungan (Chia et al., 2020). Berdasarkan analisis tersebut, pengaplikasian Biodegradasi bakteri I. sakaiensis juga berdampak terhadap lingkungan. Dibalik proses degradasinya yang cepat, ternyata I.sakaiensis memiliki struktur endotoksin didalam dinding selnya, akibatnya dapat memproduksi racun dan dibuang ke lingkungan.

Sedangkan microalga sering digunakan dalam pengaplikasian lingkungan hidup, karena mereka bersifat fotoautotrof sehinga tidak membutuhkan karbon organik untuk pertumbuhannya (Yan et al., 2016) sehingga microalga C. reinhardtii dianggap lebih ramah lingkungan dibanding bakteri I. sakaiensis.

\section{PENUTUP}

Kesimpulan yang didapat dari penelitian ini adalah apabila ditinjau dari hasil degradasi dan lama waktu pendegradasian, bakteri $I$. sakaiensis dianggap lebih efektif sebagai agen biodegradasi plastik berbahan dasar PET dibanding microalga C. reindhartii.

Di sisi lain, bakteri I. sakaiensis dianggap kurang ramah lingkungan dibandingkan dengan microalga C. reindhartii. Berhubungan dengan fakta ini, diharapkan penelitian selanjutnya dapat mengungkap cara penanggulangan dampak negatif yang ditimbulkan bakteri I. sakaiensis agar dapat diaplikasikan secara massal dalam penanggulangan masalah sampah plastik.

Penelitian ini diharapkan bisa dijadikan referensi terkait penggunaan agen biodegradasi dalam penyelesaian permasalahan sampah plastik, sehingga peluang pengaplikasian secara massal dapat meningkat. Selain itu, harapannya adalah 


\section{Jurnal Biolokus: Jurnal Penelitian Pendidikan Biologi dan Biologi Vol.4(1)}

berkembangnya penelitian-penelitian eksperimen yang relevan terhadap judul penelitian ini.

\section{REFERENSI}

Chia, W. Y., Ying Tang, D. Y., Khoo, K. S., Kay Lup, A. N., \& Chew, K. W. (2020). Nature's fight against plastic pollution: Algae for plastic biodegradation and bioplastics production. Environmental Science and Ecotechnology, 4(100065) 1-10. https://doi.org/10.1016/j.ese.2020.100065

Damayanti, Hanif, M., \& Arnesa, W.W. (2015). Pengaruh rasio berat katalis terhadap berat plastik bekas pet pada proses pirolisis berkatalis dan karakteristik produk cair yang dihasilkan. Seminar Nasional Sains \& Teknologi VI Lembaga Penelitian dan Pengabdian Universitas Lampung, 375-385.

de Castro, A. M., Carniel, A., Nicomedes Junior, J., da Conceição Gomes, A., \& Valoni, É. (2017). Screening of commercial enzymes for poly (ethylene terephthalate) (PET) hydrolysis and synergy studies on different substrate sources. Journal of Industrial Microbiology and Biotechnology, 44(6), 835-844. https://doi.org/10.1007/s10295-0171942-z

Farzi, A., Dehnad, A., \& Fotouhi, A. F. (2019). Biodegradation of polyethylene terephthalate waste using Streptomyces species and kinetic modeling of the process. Biocatalysis and Agricultural Biotechnology, 17, 25-31.

https://doi.org/10.1016/j.bcab.2018.11.00 2

Fitriyano, G. (2019). Tinjauan potensi pemanfaatan botol bekas berbahan Polyethylene Terephthalate (PET) di Indonesia. Eksergi, 16(1), 18-24. https://doi.org/10.31315/e.v16i1.2747

Han, X., Liu, W., Huang, J. W., Ma, J., Zheng, Y., Ko, T. P., Xu, L., Cheng, Y. S., Chen, C. C., \& Guo, R. T. (2017). Structural insight into catalytic mechanism of PET hydrolase. Nature Communications, 8(2106), 1-6. https://doi.org/10.1038/s41467-01702255-z

Karuniastuti, N. (2013). Bahaya Plastik terhadap Kesehatan dan Lingkungan. Swara Patra: Majalah Pusdiklat Migas, 3(1), 6-14.
Kawai, F., Kawabata, T., \& Oda, M. (2019). Current knowledge on enzymatic PET degradation and its possible application to waste stream management and other fields. Applied Microbiology and Biotechnology, 103(11), 4253-4268. https://doi.org/10.1007/s00253-01909717-y

Khan, K. S., Kunz, R., Kleijnen, J., \& Antes, G. (2003). Five steps to conducting a systematic review. Journal of the Royal Society of Medicine, 96(3), 118-121. https://doi.org/10.1258/jrsm.96.3.118

Kim, J. W., Park, S. Bin, Tran, Q. G., Cho, D. H., Choi, D. Y., Lee, Y. J., \& Kim, H. S. (2020). Functional expression of polyethylene terephthalate-degrading enzyme (PETase) in green microalgae. Microbial Cell Factories, 19(1), 1-9.

https://doi.org/10.1186/s12934-02001355-8

Knott, B. C., Erickson, E., Allen, M. D., Gado, J. E., Graham, R., Kearns, F. L., Pardo, I., Topuzlu, E., Anderson, J. J., Austin, H. P., Dominick, G., Johnson, C. W., Rorrer, N. A., Szostkiewicz, C. J., Copié, V., Payne, C. M., Woodcock, H. L., Donohoe, B. S., Beckham, G. T., \& McGeehan, J. E. (2020). Characterization and engineering of a two-enzyme system for plastics depolymerization. Proceedings of the National Academy of Sciences of the United States of America. https://doi.org/10.1073/pnas.2006753117

Mittal, A., Soni, R. K., Dutt, K., \& Singh, S. (2010). Scanning electron microscopic study of hazardous waste flakes of polyethylene terephthalate (PET) by aminolysis and ammonolysis. Journal of Hazardous Materials, 178(1-3), 390-396. https://doi.org/10.1016/j.jhazmat.2010.01. 092

Moog, D., Schmitt, J., Senger, J., Zarzycki, J., Rexer, K. H., Linne, U., Erb, T., \& Maier, U. G. (2019). Using a marine microalga as a chassis for polyethylene terephthalate (PET) degradation. Microbial Cell Factories, 18(1), 1-15.

https://doi.org/10.1186/s12934-019-220-z

Mueller, R. J. (2006). Biological degradation of synthetic polyesters-Enzymes as potential catalysts for polyester recycling. Process Biochemistry, 41(10), 2124-2128. https://doi.org/10.1016/j.procbio.2006.05. 018 
Nurhati, I. S. (2020). Peningkatan Sampah Plastik dari Belanja Online dan Delivery Selama PSBB. LIPI.

Sasso, S., Stibor, H., Mittag, M., \& Grossman, A. R. (2018). The natural history of model organisms from molecular manipulation of domesticated Chlamydomonas reinhardtii to survival in nature. eLife. eLife, 7, e39233. https://doi.org/10.7554/eLife.39233.

Seo, H., Kim, S., Son, H. F., Sagong, H. Y., Joo, S., \& Kim, K. J. (2019). Production of extracellular PETase from Ideonella sakaiensis using secdependent signal peptides in E. coli. Biochemical and Biophysical Research Communications, 508(1), 250-255.

https://doi.org/10.1016/j.bbrc.2018.11.087

Shinshi, O., \& Kogo, H. (1980). Effects of phthalic acid monoesters on mouse testes. Toxicology Letters, 6(4-5), 239-242. https://doi.org/10.1016/03784274(80)90126-5

Tanasupawat, S., Takehana, T., Yoshida, S., Hiraga, K., \& Oda, K. (2016). Ideonella sakaiensis sp. nov., isolated from a microbial consortium that degrades poly(ethylene terephthalate). International Journal of Systematic and Evolutionary Microbiolog,. 66(8), 2813-2818.

https://doi.org/10.1099/ijsem.0.001058

Thiruvenkatachari, R., Kwon, T. O., Jun, J. C., Balaji, S., Matheswaran, M., \& Moon, I. S. (2007). Application of several advanced oxidation processes for the destruction of terephthalic acid (TPA). Journal of Hazardous Materials, 142(1-2), 308-314. https://doi.org/10.1016/j.jhazmat.2006.08. 023

Triyaningsih, Sartijo, \& Prayitno, S. B. (2008). Patogenisitas Aeromonas hydrophila yang diisolasi dari lele dumbo (Clarias gariepinus) yang berasal dari boyolali. Journal of Aquaculture Management and Technology, 3(2), 11-17.

http://ejournals1.undip.ac.id/index.php/jfpik

Warlina, L. (2019). Pengelolaan sampah plastik untuk mitigasi bencana lingkungan. Peran Matematika, Sains \& Teknologi dalam Kebencanaan.

Yan, N., Fan, C., Chen, Y., \& Hu, Z. (2016). The potential for microalgae as bioreactors to produce pharmaceuticals. International Journal of Molecular Sciences, 17(6), 962. https://doi.org/10.3390/ijms17060962
Yang, Y., Yang, J., \& Jiang, L. (2016). Comment on "a bacterium that degrades and assimilates poly(ethylene terephthalate) ". Science, 353(6301), 759. https://doi.org/10.1126/science.aaf8305

Yoshida, S., Hiraga, K., Takehana, T., Taniguchi, I., Yamaji, H., Maeda, Y., Toyohara, K., Miyamoto, K., Kimura, Y., \& Oda, K. (2016). A bacterium that degrades and assimilates poly(ethylene terephthalate). Science, 351(6278), 1196-1199.

https://doi.org/10.1126/science.aaf8305 